
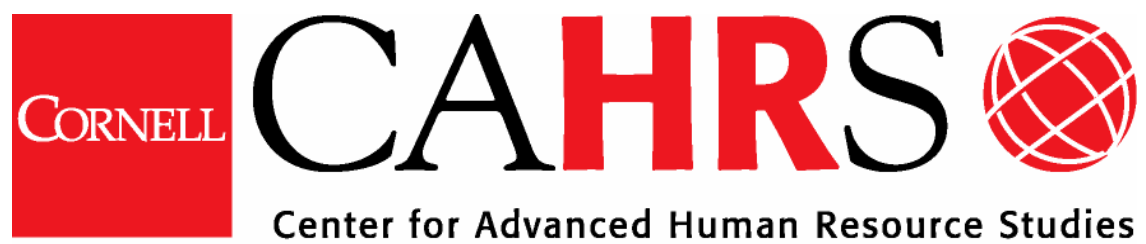

Center for Advanced Human Resource Studies

CAHRS / Cornell University 187 Ives Hall

Ithaca, NY 14853-3901 USA

Tel. 607 255-9358

www.ilr.cornell.edu/CAHRS/

UnghingPregr 马erleg

\title{
Managing Human Assets in an Uncertain World: Applying Real Options Theory to HRM
}

Mousumi Bhattacharya

Patrick M. Wright

Working Paper $04-03$

CORNELL ilr School of Industrial and Labor Relations 


\title{
Managing Human Assets in an Uncertain World: Applying Real Options Theory to HRM
}

\author{
by \\ Mousumi Bhattacharya \\ Charles F. Dolan School of Business \\ Fairfield University \\ Fairfield, CT 06824, USA \\ Phone: (203) 254-4000 ext.2893 \\ Fax: (203) 254-4105 \\ E-mail: mbhattac@mail.fairfield.edu \\ and \\ Patrick M. Wright \\ School of Industrial and Labor Relations \\ Cornell University \\ Ithaca, NY 14850 \\ Phone: (607) 255-3429 \\ Fax: (607) 255-1836 \\ E-mail: pmw6@cornell.edu
}

March 2004

http://www.ilr.cornell.edu/cahrs

This paper has not undergone formal review or approval of the faculty of the ILR School. It is intended to make results of Center research available to others interested in preliminary form to encourage discussion and suggestions.

Most (if not all) of the CAHRS Working Papers are available for reading at the Catherwood Library. For information on what's available link to the Cornell Library Catalog:

http://catalog.library.cornell.edu if you wish. 


\begin{abstract}
While many authors have proposed a firm's human resources as an asset that can provide value and competitive advantage, the SHRM field has tended to ignore the fact that assets have associated uncertainties and risks. The real options view provides a theoretical framework for how firms manage uncertainties associated with investments in real assets. We apply this logic to analyze the uncertainties associated with human assets and discuss how firms manage these uncertainties through HR 'options' which are capabilities generated by some HR practices and their combinations. We discuss these practices and develop an options model for managing different types of uncertainties.
\end{abstract}




\section{Managing Human Assets in an Uncertain World: Applying Real Options Theory to HRM}

Human assets are valuable to the firm, but their returns may not remain stable over time due to changes in business conditions, changes within the firm, or changes in individuals who own the knowledge, skill, and abilities that comprise human capital. Any discussion on the value of human resource management (HRM) for strategic outcomes is incomplete without an analysis of the uncertainties associated with human assets and the role that certain human resource $(\mathrm{HR})$ practices play in managing these uncertainties. A comprehensive theoretical framework for uncertainties of human assets and the contribution of HR practices in building capabilities for managing them, would not only provide a rationale for adopting these practices, but also would highlight a hitherto unexplored area in strategic HRM. In this paper we address this issue.

Although a number of studies have established the positive linkage between high performance HR practices and superior firm performance (e.g., Arthur, 1994; Delery and Doty, 1996; Huselid, 1995), researchers have also called for examining how these HR practices translate into greater firm performance (Becker and Gerhart, 1996; Delery, 1998; Wright and Sherman, 1999). Becker and Huselid (1998) suggest two primary processes through which this impact takes place. First the "...HRM-firm performance relationship could be largely driven by a more efficient management of a firm's HR, and the consequent contribution to lower operating costs..." ( $p$ 56), which translates to HR practices being a set of "cost reducing" techniques. Second, they suggest that HR practices can impact firm performance through influencing the development of human capital as a strategic asset. Grounded in the resource-based theory, Becker and Huselid (1998) argue that systems of HR practices are inimitable and are the basis for the "...acquisition, motivation, and development of the intellectual assets that can be a source of competitive advantage" (p. 55). Strategic HRM researchers have focused more on this latter process where HR practices are hypothesized to impact the intellectual capital (or 
human capital), which is viewed as one of a firm's most strategic assets (Snell, Youndt, and Wright, 1996; Wright, McMahan, and McWilliams, 1994).

However, this treatment of the human capital as an asset, has universally focused only on the upside value inherent in an asset. If one accepts the argument that human capital should be treated as an asset, then one necessarily must recognize that, like any asset, human capital also entails uncertainties of return and part of the strategic management of the firm requires managing these uncertainties. The issue of managing uncertainties of human assets has been unexplored in the strategic HRM, leaving a gap in existing theory. Absence of analysis of the uncertainties of human assets may cause over emphasis on their value and the role of different HR practices in maintaining the value of human assets may be underestimated. Our paper addresses this gap in the literature and provides an alternative theoretical rationale for how HR practices may create or maintain value of human assets. We offer a theoretical framework that investigates the link between uncertainty, HRM, and firm capabilities to manage uncertainty.

In order to discuss uncertainties of human assets, we present the 'real options' view currently popular within the strategic management literature, which enables decision makers to evaluate investment opportunities in uncertain environments and highlights how these investments create value through future choices. Real options theory is complementary to the resource-based view in explaining the significance of firm resources and capabilities for competitive advantage (Leiblen, 2003). Although the resource-based view explains how resources and capabilities contribute to firm performance, it does not address the issue of how managers may develop them. Rather it assumes that firms have (somehow) made upfront investments in the processes of creating resources whose eventual value is inherently ambiguous and uncertain (Leiblen, 2003). This gives rise to the notion of resource heterogeneity and resource immobility arising out of history-driven causal ambiguity. Real options theory, on the other hand, explicitly addresses the issue of investment choices for future resources and capabilities. It assumes that managers develop a level of foresight sufficient to invest in 
resources and processes with 'options' characteristics that provide implicit or explicit claims on future opportunities and generate flexibilities for future investments (Leiblen, 2003). In other words, it analyzes how firms can lay claim to future rent-generating capabilities through investment in options. Real options theory is similar to the resource-based view in claiming that present resources and capabilities arise out of past investments. However it goes further in specifying how time-deferred choices and operational flexibilities can add value for investments in resources and processes with uncertain returns. (Leiblen, 2003). The options framework offers an economic logic for incremental, path-dependent resource investments (Bowman and Hurry, 1993), and specifically addresses the issue of finding a superior mechanism of resource allocation (McGrath, Ferrier, and Mendelow, 2004), which the resource-based view lacks.

Our paper uses the real options framework to analyze the uncertainties in strategic HRM and how HR practices generates capabilities or 'options' for managing the uncertainties, thereby creating value for the firm. In the following sections, we provide a brief overview of the real options framework, focusing on the uncertainties that it seeks to address; apply this framework to identify the types of uncertainties associated with human assets; and examine the implications of this framework for making decisions regarding investments in human resources through HR practices.

\section{Real Options Theory.}

Real options theory applies the concepts of financial options to investments in real assets. Financial options are contracts written on assets that are perfectly tradable in the market (stocks, commodities, currency), conferring rights to buy or sell the assets at a predetermined price within a pre-determined date. Options are created due to uncertainties about future returns from investments - the greater the volatility of the underlying asset price, the higher is the uncertainty about returns from that asset. Investments in options are made to manage risks of depreciation of value, or to avail of the benefits of future appreciation of value.

Real options are created on real assets, which are somewhat different from financial assets. Real assets are acquired through investments of time, effort, and money; generate 
returns over a period of time; carry the risk of depreciation of value, and the opportunity for appreciation of value (Amram \& Kulatilaka, 1999). However, unlike financial assets, real assets may not be perfectly tradable in markets; may be tangible (e.g., real estate, plants and property, patents, joint ventures) or intangible (e.g., brand name, reputation, organizational learning capabilities); and may not be valued fully or explicitly due to presence of invisible components.

A firm invests in real assets to generate returns over time, but there are uncertainties associated with the returns. For example, real estate values fluctuate over time, new products may not be successful, and an acquisition may become too costly. The real options theory (Bowman \& Hurry, 1993; Dixit, \& Pindyck, 1994; Trigeorgis, 1996) analyzes uncertainties related to real assets and suggest that 'options' created on these assets will reduce risks of loss of value and increase future opportunities for returns. Real options are implicit or explicit capabilities created for real assets that provide the firm time-deferred and flexible choices regarding future investments in these assets (Kogut and Kultilaka, 2001; Leiblien, 2003). Through these capabilities, the firm may choose to adjust, reduce, increase, or abandon the investment in the future, thereby stabilizing returns from these assets.

In real options view, uncertainty is the randomness of outcomes from an investment decision (Amram and Kulatilaka, 1999). Uncertainties may be of different types and may arise from different underlying sources (Dixit and Pindyck, 1994; Trigeorgis, 1996). For example there may be uncertainties regarding future value of an asset or the cash flow generated from it (uncertainty of returns); regarding volume of operation or combination of resources and processes (uncertainty of volume or combinations); or regarding continuing costs of investments (uncertainty of costs). These uncertainties can arise from changes outside the firm (external factors) or changes within the firm (internal factors). Regardless of the source or the type of uncertainty, the basic argument of real options theory is that firms can make investment decisions in ways that can reduce downside risk and/or enhance the scope to capitalize on opportunities that the uncertainty creates. As Amram and Kulatilaka note: 
"In rethinking strategic investments, managers must try to view their markets in terms of the source, trend, and evolution of uncertainty; determine the degree of exposure for their investments; and then respond by positioning the investments to best take advantage of uncertainty (1999:14)."

\section{Human Assets and Uncertainty}

A firm's human asset consists of the employees and the collection of their knowledge, skills, and abilities, also known as human capital. The firm can 'buy' the human capital by hiring employees; and it can 'make' human capital through training, job experience etc. Several researchers have discussed human capital as a valuable strategic asset for the firm (Becker and Huselid, 1998; Snell, Youndt and Wright, 1996; Wright, McMahan, and McWilliams, 1984). Hamel and Prahalad (1994) and Ulrich and Lake (1990) discuss how people are the main sources of 'competencies' and 'capabilities' of the firm. Most of the capabilities that a firm possesses can be linked to human capital and therefore this form of asset is considered critical for creating and sustaining competitive advantage.

However, human assets, like other forms of assets, have several uncertainties associated with it. The future value of human assets can be uncertain (e.g. performance of employees may go down over time or job responsibilities may change causing a misfit between the person and the job), which, as per real options theory, is uncertainty of returns. The number of employees demanded may fluctuate according to market conditions or there may be unexpected demands for skills that the employees do not possess. Real options scholars have called this uncertainty of volume and combinations. Furthermore, costs of human assets, in the form of wages, salaries, benefits etc., may also be uncertain (e.g. significant rise in health benefit costs or high fixed costs vis-à-vis low cash flow of the firm), which real options scholars have referred to as uncertainty of cost of continued investments. Consequently, any investment in human assets, from the decision to acquire (employ), develop, motivate, or retain employees, carries with it uncertainty regarding the future return from that investment, and the risk that the payoff may not be as expected. 
For example let us consider the scenario where an employee has been with a firm for several years. Although his experience is valuable, he does not have additional skills. In a recent development the firm decides to offshore his job and has two choices for him - either lay him off and lose his expertise and firm specific human capital, or fit him into another job. The latter becomes difficult if he is not adaptive, leading to high uncertainty of return from the individual. In the second scenario, the employee is flexible and willing to learn new skills, but the firm does not provide suitable learning opportunities or training. This creates a misfit with the changed demand pattern, leading to risk of loss of value of his human capital. In the third scenario, the employee is trainable and the firm provides training, but his fixed remuneration is high, which makes him expensive for the firm - resulting in uncertainty of cost. Finally, we consider the scenario when all these conditions are met i.e. willingness of the employee to learn, opportunity by the firm to learn, and variable pay; but changed demand requires him to relocate, which is difficult for him due to family obligations. This gives rise to uncertainty of combination. In addition, a unique uncertainty associated with human assets is that the employee may leave voluntarily, thereby taking valuable human capital away. Each of these scenarios assumes that the employee is valuable and the firm wishes to retain him, else the option to 'disinvest' the employee through layoff is open (although that may not be the case in some countries of the world where layoffs are not easy).

As seen in the above scenarios, uncertainty of human assets can come from the firm, due to things such as changed strategic direction, or from the market, as business conditions, customer needs and competitor actions change. However, in exploring a real options approach to managing human assets, we need to recognize that uncertainties can also arise from individuals because one way in which human capital differs from real assets is that the firm does not own the capital; the employee does. Consequently each employee makes behavioral choices, and these choices may or may not be predictable. Thus, in addition to the firm and the market, the individual serves as a potential source of uncertainty for human assets. 
Table 1 lists the uncertainties associated with human assets and the factors that contribute to it at the individual, firm and market level. Uncertainties of human assets can be related to returns, volume, combinations, and costs. Uncertainties of returns refer to the depreciation (or appreciation) of value of human assets and variations in the value generated by it. Skill obsolescence, demand for future skills not possessed by the individuals, loss of human capital and loss of productivity are some examples of uncertainties of return of human assets. Uncertainties of volume are fluctuations in the demand and supply of the quantity of human assets, both inside and outside the firm; while uncertainties of combination are unforeseen changes in deployment of this asset giving rise to the need for reallocation. Uncertainties of costs are the variations in the ratio of the total outlay for human assets relative to firm revenues. High and fixed employee costs and fluctuating firm revenues give rise to uncertainty of costs for human assets. We now explore the factors affecting these uncertainties in the following section.

Table 1

Uncertainties of Human Assets

\begin{tabular}{|c|c|c|c|}
\hline \multirow{2}{*}{ UNCERTAINTIES } & \multicolumn{3}{|c|}{ SOURCES OF UNCERTAINTIES } \\
\hline & INDIVIDUAL & FIRM & MARKET \\
\hline $\begin{array}{l}\text { Uncertainties of return } \\
\text { - Skill obsolescence } \\
\text { - Demand for future } \\
\text { skills } \\
\text { - Human capital loss } \\
\text { - Loss of productivity }\end{array}$ & $\begin{array}{l}\text { - Erosion of existing skills } \\
\text { - Inability to learn new } \\
\text { skills } \\
\text { - Employee } \\
\text { dissatisfaction, lack of } \\
\text { commitment } \\
\text { - Voluntary turnover }\end{array}$ & $\begin{array}{l}\text { - Skill profile mismatch with market } \\
\text { requirements } \\
\text { - Turnover of critical skill group } \\
\text { - Inability to generate/accommodate } \\
\text { new skills and learning } \\
\text { - Inability to institutionalize } \\
\text { knowledge } \\
\text { - Lack of employee development } \\
\text { - Lack of concern for employees }\end{array}$ & $\begin{array}{l}\text { - Demand for new skills } \\
\text { - Uncertain supply of new } \\
\text { skills } \\
\text { - Uncertain demand for } \\
\text { existing skills } \\
\text { - Changing career patterns }\end{array}$ \\
\hline $\begin{array}{l}\text { Uncertainties of volume } \\
\text { and combinations } \\
\text { - Variations in number } \\
\text { of employees required } \\
\text { - Variations in } \\
\text { deployment of human } \\
\text { assets }\end{array}$ & $\begin{array}{l}\text { - Absenteeism, leave } \\
\text { - Resistance to changes } \\
\text { in work arrangements }\end{array}$ & $\begin{array}{l}\text { - Variations in demand for number of } \\
\text { employees in different units/jobs } \\
\text { - Lack of slack/buffer, high human } \\
\text { capital leverage }\end{array}$ & $\begin{array}{l}\text { - Variations in demand for } \\
\text { and supply of goods and } \\
\text { services }\end{array}$ \\
\hline $\begin{array}{l}\text { Uncertainties of costs } \\
\text { - Variations in total } \\
\text { employee outlay vis-à- } \\
\text { vis cash flow }\end{array}$ & $\begin{array}{l}\text { - Overuse/misuse of } \\
\text { benefits } \\
\text { - High guaranteed } \\
\text { pay/bonuses }\end{array}$ & $\begin{array}{l}\text { - Variations in profitability } \\
\text { - High financial leverage }\end{array}$ & $\begin{array}{l}\text { - Business cycles } \\
\text { - Competitive pressures for } \\
\text { cost reduction }\end{array}$ \\
\hline
\end{tabular}




\section{$2.1 \quad$ Uncertainties of Returns}

At the individual employee level, uncertainty of returns may stem from skill obsolescence or inability to learn new skills. Employee skills may become obsolete or eroded if the employee is unable to upgrade skills or learn new skills as demand changes. In today's economy the pervasiveness of complex technology in all spheres of business and the fast rate of change in technology create greater risks that an employee is unable to keep up with these changes or is unable to learn new skills. Therefore performance of an employee may not remain the same over the years and return on investments in human capital may be affected. If employees do not adapt their skills and knowledge to the changed circumstances, or are unable to learn fast, obsolescence of skills become a major risk for the firm.

A major difference between human assets and other forms of real assets is that the firms never 'possess' human assets in the true sense. Employees may leave the organization at their will, taking critical skills with them, resulting in human capital loss. Voluntary turnover has become a major risk for organizations, especially in the higher management and critical skill category where demand exceeds supply. Research on turnover has found that individual factors like overall job dissatisfaction arising from dissatisfaction with pay/promotion/supervisory relations, as well as dissatisfaction with job content like autonomy, responsibility etc. are predictors of voluntary turnover (Griffeth and Hom, 1995). Therefore we identify employee dissatisfaction and lack of commitment as individual level factors that increase uncertainty of returns.

Even if the employee do not leave the organization, uncertainty of returns from human assets can rise from loss of productivity due to employee dissatisfaction, lack of motivation and/or lack of commitment on the part of employees. As Wright, Dunford, and Snell, (2001) explain, employee behavior is extremely important in determining the effect of human capital on firm performance, and skill and knowledge are worthless unless employees choose to use them through their behavior. Only motivated and committed employees can translate their skills into 
performance, and to the extent that motivation and commitment varies and employees do not actually contribute to the level of their potential, uncertainty of returns may arise.

At the firm level, the sources of uncertainty of return are related to the skill profile of the firm i.e. the combination of skills or skill sets that the firm possesses. According to Lepak and Snell (1999) not all groups of human capital are equally valuable to the firm; some are higher in value and uniqueness than others. The demand for skills (and consequently, the value of different skills in different employee groups) is largely dependent upon the firm's overall strategy. Over time, due to shifts in strategy, and employee turnover, the skill profile of the firm may become misaligned with that required by the firm's strategy. For instance, IBM's recent strategic migration from manufacturing to services has resulted in disengaging human capital through selling divisions and laying off employees in one area while simultaneously acquiring human capital through hiring and business acquisitions (e.g. PriceWaterhouse Coopers). Additionally, for a firm, a critical skill group may get depleted due to voluntary or natural turnover. If a firm fails to support adequate learning, or generation of new skills, or cannot institutionalize knowledge, then the effect of such skill-profile mismatch or skill depletion will be profound and uncertainty of returns will be high. Therefore lack of employee development can contribute to skill crisis over time. In addition, a firm's lack of concern for employees, as manifested in absence of support for work-family balance, stressful work environment etc. can lead to employee dissatisfaction, poor motivation and less commitment that may result in loss of productivity due to non-optimum effort on the part of employees to apply their knowledge, skills and abilities.

Market factors that give rise to uncertainties of return are related to demand for and supply of skills. The external labor market provides a set supply of various skills that may or may not be needed by the organization. Critical and new skills may become scarce and uncertain, or there may be shortage of required skills due to changing career patterns. For instance, within the IT industry, the year 2000 bug created a short term demand for programmers with COBOL skills, but because this programming language was outdated, the 
market had a low level of supply of such skills. Recently due to heavy retirement of babyboomers and increasing need for medical treatment of aging population, there is an acute shortage of nurses in the U.S.; however supply is not picking up as it is not an attractive career choice in terms of working hours and remunerations.

In large part, it is the interface of the supply of the market with the demand of the firm that creates the uncertainty of returns from human capital. Environmental forces like fast changes in business conditions, greater complexity in business, rapid internationalization, changes in technology, new competition, and innovation impact the skill demand of firms through requiring different skills of employees (rapid learning, global perspectives, creativity, etc.). For example, Gale, Wojan, and Olmsted (2002), in a study of 2800 manufacturing establishments, reported that most employers said that with increased modernization of technology, skill requirements from employees were growing rapidly, especially for computer, interpersonal, and problem solving skills. These changes may create a skill profile mismatch with the market demands, making returns from human capital highly uncertain.

\subsection{Uncertainties of Volume and Combinations}

Uncertainties of volume arise due to fluctuations of demand and supply of the number of employees. Individual factors like absenteeism, leave, or work stoppages can present the firm with unexpected short-term losses of human capital. Consequently, given a set volume of production, the inability to predict the volume of employees at work presents risk. For example, a firm experiencing a $10 \%$ absenteeism rate might set its workforce numbers at a level to maintain required production with $10 \%$ absent. However, on days that only $5 \%$ of employees are absent, the firm overpays, and on days that $15 \%$ are absent, it is unable to produce at the expected volume.

Firm factors such as fluctuations in their human capital demands (say, due to changes in technology), also presents uncertainty. When demand is uncertain, employing a large number of full time or permanent employees is a risk. (Note that this form of risk assumes a stable skill set and thus is distinct from risks associated with skill obsolescence, non-availability, or capital 
loss). Variations in firm demand may arise from internal scheduling, or from market factors like variations in demand and supply of goods and services. For instance, as Boeing entered a price war with Airbus in the midst of the recession during the early 1990's, their econometric models predicted that the demand for planes from airlines would begin its upturn 2 years later. This led them to lay off 12,000 employees. However, a faster than expected recovery and Boeing's use of "sole supplier" contracts resulted in a sudden surge in demand for their products, a level which exceeded their human capital pool's ability to produce.

Uncertainties of combination arise when there is a need to reallocate employees or their skills within the firm due to qualitative/quantitative variations in demand and supply. This is different from uncertainty of volume because combination may involve change in work location, while volume is change in numbers. For example day to day scheduling may require shifting of employees around different operations as per requirement. This may also be necessary for reducing employee costs or for keeping costs under control. If employees do not have the breadth of skills or knowledge necessary for redeployment, or if they resist these changes, then uncertainty of combination of human assets, that is the risk that deployment requirements will not match the supply, is high. Therefore, at the individual level, uncertainties of combination may arise from resistances to changes in work arrangement or non-adaptability.

At the firm level lack of slack/buffer in human capital or high human capital leverage, as well as variations in demand for number of employees in different units/jobs may lead to the necessity for changes in deployment. At the market level, variations in demand for and supply of goods and services lead to uncertainties of volume and combination. For example, a few years ago Sun Microsystems faced a variety of challenges across its seven business units. Because they did not have an internal communications/job posting system in place, they laid off a number of employees in one shrinking division whose skills matched the needs in other growing divisions. The layoffs incurred significant and unnecessary tangible (severance pay) and intangible (job insecurity) costs in the shrinking division, while simultaneously incurring tangible 
(recruitment and search) and intangible (overwork) costs in the growing division. A reallocation of employees may have saved costs, while preserving human capital.

\subsection{Uncertainties of Costs}

Uncertainties of costs are associated with the high and fixed costs of employees, especially when revenues are volatile. These are manifested through employee cost escalations and need for cost reductions. A major constituent of overall costs of the firm, employee costs, if too high, are a big drag on the firm's cash flow, especially when revenue fluctuates (as seen in the semiconductor industry). Additionally, if employee costs are mostly fixed, then a firm with fluctuating revenue faces the risk of loss in case of downturns in revenues.

Lack of awareness of costs or overuse/misuse of benefits, on the part of individual employees, may lead to high employee costs. For example, in recent years a steep rise in health care benefits costs has led to increased employee costs for many firms (although this may not entirely be attributable to the employees). Many mature companies such as General Motors exemplify uncertainty of cost through their legacy pension and health care obligations. As GM has downsized over the years, it has created a growing number of retired employees to whom the company owes pension and health care. This tremendous cost of a legacy workforce must now be supported by a decreasing workforce and over a decreasing sales base. High levels of guaranteed pay, bonuses, and overtime for a large group of employees also add to uncertainty of employee costs. In addition mismatch of individual human capital to tasks leads to waste and higher costs (e.g. poor selection practices where company hires someone with more skills than required; or seniority-based retention during downsizing that can lead to overpaying for skills and experiences that are not being used).

At the firm level, firms that operate on leveraged financing with a high debt-equity ratio, have more pressure on cash flow due to loan servicing requirements. This might lead to greater uncertainties because even moderate increases in employee costs put high pressure on their cash flow. Also performance of firms varies widely; the 'blue-chip' firms have relatively stable performance over the years, while small and highly leveraged firms may have greater 
fluctuations in performance. Greater variations in revenues, as seen in recent years, give rise to higher uncertainties of costs if most of the employee costs are fixed in nature. At the market level, competitive pressures for cost reduction (when competitors achieve cost reductions) as well as decrease in profits and cash flow during downturns in business cycles may lead to greater uncertainties of costs for the firm. For instance, returning to the legacy workforce pension and health care costs being experienced by a number of US automakers, it is important to note that their overseas competitors face nowhere near the same pension and health care obligations. In addition, the cost of their obligations can be amortized over a growing sales base and growing number of workers. This enables them to undercut US automakers on price.

Real options theory predicts that uncertainties of different assets would be different based on the number of factors involved and the degree of severity of each factor (a number of scholars are working on appropriate mathematical models to fit different uncertainty profiles). For human assets, the importance and relevance of different sources of uncertainty vary across levels within the firm, among different organizations, and through different time periods. Firms may experience more different types of uncertainty for different employee groups depending upon industry, strategy, environment, or time periods. Also, different sources of uncertainty may be interrelated and interdependent so that one lead to the other. Therefore the overall risk of human capital consists of the effect of different factors at different levels.

\section{Options and Human Resource Management}

Because human capital has uncertainties, a firm needs to manage these uncertainties so that they do not affect overall performance. Firms typically respond to adverse business conditions by downsizing, thereby losing valuable human capital with potentially adverse effects on firm performance (Cascio, 2002; McElroy et al., 2001). Real options theory recommends that firms should develop capabilities, i.e. combination of resources and processes, to manage uncertainties proactively so that they can respond when sudden changes occur. These capabilities are, in essence, 'options' (Kogut and Kulatilaka, 2001) because they reduce the costs of adjustments when changes occur, preserve value, and create flexibilities of decision 
and operation. However, only the capabilities which allow the firm to heuristically act upon uncertainty can be considered options (Kogut and Kulatilaka, 2001). In other words although many real options are capabilities, not all capabilities are options.

An option is an investment in assets that provides the capability to respond to future contingent events landscape (Kogut and Kulatilaka, 2001) and manage uncertainty (Trigeorgis, 1996). Through options investments the firm proactively seeks to exploit uncertainty, rather than absorb it, by building capabilities that provide the appropriate flexibility for a stochastically changing landscape (Kogut and Kulatilaka, 2001). Thus an option has value only if there is uncertainty. The value of a financial option depends only on the price of the underlying asset because the source of uncertainty is the market price of traded asset (e.g. stock). However, as discussed above, the sources of uncertainty of real assets may be multiple and not quantifiable, such as changes in the business conditions (e.g. demand and supply), changes in the intrinsic value of the assets, or changes in the cost of investments. Therefore real options create value by allowing the firm to operate flexibly (Trigeorgis, 1996), by creating opportunities for learning (Amram and Kulatilaka, 1999; Trigeorgis, 1996), and by reducing the costs associated with exploration and growth in new markets (Kogut and Kulatilaka, 2001).

We use the above rationale to discuss how some HR practices may generate capabilities that have options characteristics to reduce costs and/or exploit opportunities associated with uncertainties of human assets. HR practices are mechanisms through which the human capital of the firm are acquired, maintained, and motivated. Thus through HR practices, the firm invests in its human capital and manages them. Scholars in the strategic HRM literature have demonstrated that many HR practices have positive impact on firm performance (Arthur, 1994; Delery and Doty, 1996; Huselid, 1995). The predominate explanation of how these practices translate into value for the firm has been that of the resource-based view, i.e. these practices create valuable human capital. However this explanation does not address how the value can be preserved in dynamically changing business conditions which result in uncertainties of human capital. The resource-based view assumes a complex, ambiguous, and 
inimitable process through which managers somehow arrive at the valuable human capital and maintain it.

We use the framework of real options theory, to provide an alternative explanation of how some of these HR practices may create value for the firm. This framework allows the managers to estimate the uncertainties associated with human assets, and invest accordingly in 'option' to manage them. This way, managers can act proactively on uncertainties and preserve or enhance the value of human capital. However it is important to note that options require additional investments, which are 'premiums' (in real options notations), for which returns are not immediately available. These are irreversible costs for creating the option, and needs to be considered upfront against the benefits accrued. Moreover, in future, the option may 'expire' in the sense that the capabilities may not be used and over time may be lost (we'll discuss the issue of expiry for different HR options in the next section). Therefore using the options logic necessarily entails a rigorous analysis of human assets, their uncertainties, and costs of creating the options, all of which contribute towards a greater understanding of the strategic role for HRM.

\subsection{HR Options}

HR options are investments in the human capital pool of an organization that provide the capability to respond to future contingent events. HR options enable the firm to develop and deploy human capital in order to limit downside risk and create opportunities for greater returns in the future. Because of inertia, firms cannot easily adjust capabilities of its human assets to changed business conditions; only those who have made investments in appropriate HR capabilities are able to respond. Therefore the value of HR options lie in allowing the firm to proactively respond to uncertainties of human assets.

HR options are generated through certain HR practices. HR practices are routines or processes through which a firm acquires, maintains, and motivates its human capital. In other words a firm manages its human capital through various HR practices. Many of these practices are aimed at building a human capital pool able to deliver returns in the current time period 
under current conditions. However, some HR practices are also aimed at building a human capital capability to respond to future uncertain events (Wright and Snell, 1998). We focus on these practices and discuss how they build capabilities to manage future uncertainties.

While we limit our discussion to specific HR practices, we recognize that there are firm processes and routines outside of these practices that may also generate HR options. For instance, leadership behavior, efforts to build or maintain culture, and communication, all may entail costs and create future value through binding employees emotionally and behaviorally to the firm. Thus, not all HR practices are options, and not all HR options are HR practices.

Moreover, HR options do not act in isolation. In fact real options theorists point out that multiple interacting options may be more effective than individual ones (Trigeorgis, 1996). This is especially relevant for human assets because reinforcements from different HR practices are needed to bring about desired changes in human capital.

Figure 1 illustrates the types of uncertainties and the HR options that manage them.

These are discussed below.

Figure 1

Human Resource Options

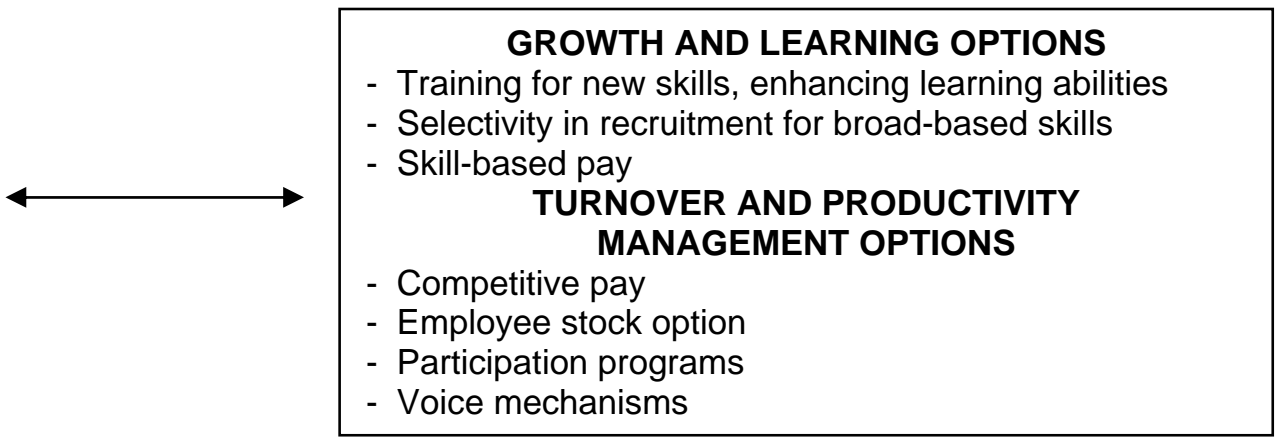

UNCERTAINTIES

OF VOLUME AND COMBINATION

- Variations in number of employees required

- Variations in deployment of human assets

\section{UNCERTAINTIES} OF COST

- Variations in total employee outlay vis-à-vis cash flow

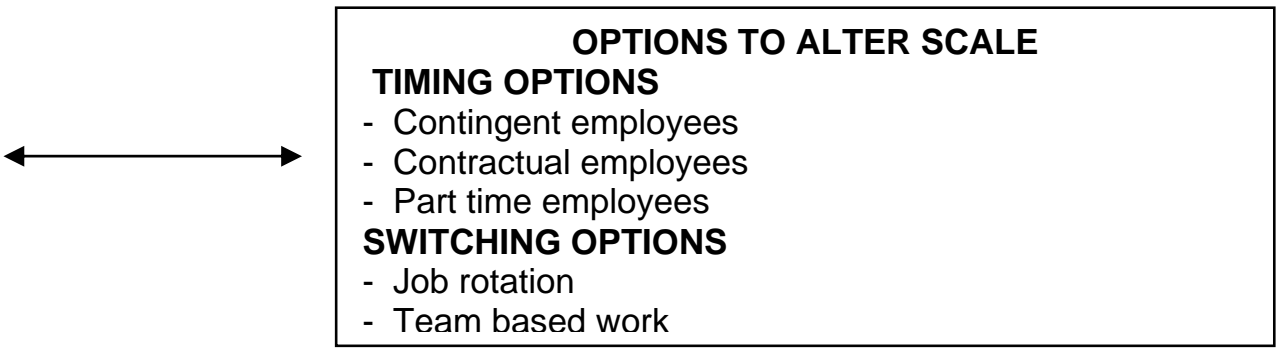

$\longleftrightarrow \begin{aligned} & \text { OPTIONS TO ALTER COSTS } \\ & \text { - Variable pay } \\ & \text { - Performance-based incentive plans at the firm/ unit level } \\ & \text { - Defined contribution pension plans }\end{aligned}$


Managing uncertainties of returns. We propose that firms facing higher levels of uncertainties of returns should invest more in growth and learning options to manage them. Growth options are capabilities that reduce risks of loss of value and create future growth opportunities (Amram and Kulatilaka, 1999), while learning options are investments that foster learning. Training for new skills and improved learning abilities, selectivity in recruitment for broad-based skills, and skill-based pay create growth and learning options to manage risks of skill obsolescence and demand for future skills.

Management of risks related to skill obsolescence demands that the firm develops a broad inventory of skills so that there is continual supply of new or different skills, or that they foster 'learning.' Training imparting new skills or modified skills that may be required in the future (sometimes distinguished as "development" rather than training) is suitable for managing this type of risk. Risks of skill obsolescence vary according to the type of skill. For example, driving skills do not become obsolete as fast as computer skills. Therefore training programs should be related to the degree of risk of skill obsolescence. Firms requiring skills that could quickly become obsolete should have more training programs geared towards continuously upgrading these skills. These types of training build future skill capabilities, i.e. growth options, which give the firm choices for minimizing the risks of skill obsolescence and meet demands for future skills. Similarly, training for improving learning abilities generate learning options, which prepares the employees to adopt easily.

Firms can also invest in growth options for their human assets through recruitment. Selectivity in recruitment refers to setting higher standards for choosing the employee to hire. Selectivity may be manifested in several ways, by requiring college or professional degree, by administering selection tests, by collecting a wider pool of applicants. Selecting for broad-based skills and learning abilities (as tested through general ability tests etc.), rather than for specialized skills, creates growth and learning options because such employees are trainable and can upgrade their skills easily (Colquitt, LePine, and Noe, 2000). We consider selectivity in recruitment for broad-based and learning skills to be instrumental in generating HR growth and 
learning options that limit risk of skill obsolescence, and foster future growth opportunities through new skills and learning capabilities.

Another HR practice that helps maintain updated and market-specific skills is the skill based compensation plan. Murray and Gerhart (1998) noted, "By paying for attributes (knowledge, skills, and abilities) of individuals, organizations hope to direct the attention of their employees to developmental opportunities and to encourage skill-seeking behavior" (pp. 68). Snell and Dean (1994) suggest that person contingent skill-based pay rewards continuous learning and derives value from increased flexibility in a dynamic environment. Researchers have found positive linkages between skill-based pay and firm performance (Murray and Gerhart, 1998). Skill based pay creates opportunities for developing multiple and broad-based skills, manage risks of skill obsolescence and generate options because employees are rewarded for learning new skills and developing a broad array of talents (Lawler and Ledford, 1985).

Combining the above, we propose that,

Proposition 1: Firms that have greater risks of skill obsolescence and greater demands for new skills should create greater number of growth and learning options through practices like training for new or upgraded skills, fostering learning, selectivity in recruitment for broad-based learning skills, and skill based compensation plans.

Note that in order to create growth and learning options the firm must pay a premium in the form of the costs of training that might not benefit the firm in the short run, or compensation for skills that might not be fully utilized in the present. This is same as the premium paid to acquire a financial or real option and may be lost if the capability is not utilized. However, while financial options have pre-determined expiry dates, and real options may also expire within a time limit (e.g. expiry of a lease agreement), it is difficult to judge when HR options 'expire.' For example a learning capability may be sustained for a while and an employee with broad-based skills may be valuable for a longer period of time. 
Turnover of employees represents risks of human capital loss. Consequently, firms seek to invest in the capability to bind human capital to the firm as much as possible. Turnover is managed through HR practices like highly competitive pay, employee stock options, participation programs, voice mechanisms, and attractive benefits packages. Firms pay competitive salaries in order to attract and retain the skills they need. The higher the value of the skills, the higher is the competitiveness in pay. In this sense, the firms pay a 'premium' for the skills that are more critical for the firm. Employee stock options are a form of deferred pay. Employees are given options for buying stock of the company on a later date at a price below the expected market price. This is an incentive to the employee to stay with the company (the stock options may not be exercisable if they leave the company).

Programs that allow for employee participation in decision-making (participative committees, quality circles etc.), voice mechanisms (grievance procedure, suggestion schemes), attractive benefits packages (401K plans for retirement with high employer contribution, health insurance, life insurance, disability insurance, cafeteria plans for dependent care and medical expenses, health club memberships, child care assistance, tuition-remittance for self or dependants etc.), as well as flexible work arrangements are all various HR practices for attracting employees and motivating them to stay with the company. There is evidence that many of these practices improve employee morale and satisfaction with their job. For example Peterson and Tracy (1992) found that employee involvement in joint problem-solving committees in unionized setup significantly reduced employee grievances. Wager (1997) found support that positive labor-management relationship in the form of prompt settlement of grievances, perceived fairness in employment conditions on the part of employees, joint problem solving by union and management, management seeking input from the union before initiating changes, and the practice of free exchange of information, have positive effect on perceived employee performance. Shaw, Delery, and Gupta (1998) show that greater benefits and procedural justice significantly reduce quit rate of employees. 
These HR practices build the capability of the firm to attract, motivate and retain employees as well as to signal to the employees that the firm cares for them. Therefore these are HR options to manage employee turnover and productivity. We hypothesize that firms that face greater risks of employee turnover and loss of productivity should use these HR practices to manage the risks.

Proposition 2: Firms that have greater risks of employee turnover and loss of productivity should create HR options to manage them through practices like competitive pay, employee stock options, participation programs, voice mechanisms, attractive benefits etc.

These options are aimed at putting the choice to separate in the hands of the firm, thus enabling the firm to manage the uncertainty. Like before, note that creating the option requires a firm pay premium in higher short run costs, but these costs are incurred in order to manage the risk of loss of productivity and the human capital asset in the future. It is also difficult to ascertain when these options expire - for practices like participation program, voice mechanisms, the option may expire if the program is discontinued. For competitive pay, the capability to retain employees may be lost if market pay shifts further upwards, unless the firm continues to make market adjustments. For employee stock options, the effect will be lost when options are vested. However implicit in each of these options is the psychological contract (of being a good place to work at) that the firm signals to employees, which may last longer than the actual option itself.

Managing Uncertainties of Volume and Combination. Uncertainties of volume arise because of fluctuating demands in terms of numbers of employees. Use of contingent, parttime, and contractual employees create capabilities that allow the firm to alter operating scale i.e. vary the total number of employees, according to fluctuations in demand. Purcell (1998) discusses how use of contingent labor is increasingly becoming associated with high performance HRM; while Foote and Folta (2002) analyze how temporary workers create options for the firm. For example retail outlets hire temporary employees during the holiday season, 
many companies implement projects through external consultants, hospitals fill a number of positions through part time or temporary employees, schools hire temporary employees for substituting.

Use of contingent, part-time, and contractual employees may also be considered as timing options in relation to acquisition of human skills for which uncertainties of future demand exist. Timing options manage uncertainties of volume by 'deferring' or 'staging' the investment. Through these options the firm has the choice not to commit itself fully in the current period in acquiring these skills. The firm 'leases' the human capital in the form of contractual/temporary employees or it may 'stage' investment in the form of part time employees. For example, CNA Insurance Company manages most of their major IT projects through outside contractors because of the uncertainty of continuation of demand. At the same time these practices allow the firm to invest in future opportunities by leasing the skills that may become critical in the future. The firm has the choice in the future to internalize these jobs, depending on actual demand conditions. The option to 'abandon' i.e. the choice to give up the investment in order to minimize losses, is inherent in these HR practices. For example the CNA recently closed down its Detroit IT center, terminating most of the IT contractual employees.

Thus, we postulate that firms that face greater fluctuations of volume should employ greater number of contingent, part-time, contractual employees.

Proposition 3: Firms that have greater uncertainties of volume should create HR options to alter operating scales as well as timing options in the form of contingent, part time, and contractual employees.

Matusik and Hill, (1998) noted that the use of contingent workers sometimes results in higher costs, in the short run. However, these costs are incurred to provide the necessary flexibility, which may offset the costs in the long run. Such costs can be considered the option premium. In terms of option expiration, the use of contingent worker may continue if uncertainty of volume persists, and the option to alter scale does not expire. On the other hand, if the firm 
chooses not to internalize the job and continue to employ contractual/part-time employee, the timing option may expire as now the contractual employee becomes routine employee at a higher cost.

Uncertainties of combination arise when there is a need for reallocation of skills within the firm due to variations in demand and supply. The challenge in developing the capability to reallocate skills is to identify suitable candidates, to convince them, and to induce them to perform at their best in their new job. HR practices that generate capabilities to manage uncertainties of combination are job rotation, and team based work. Many companies formally or informally rotate employees among different kinds of jobs in order to develop multiple skills as well as to create flexibility of skills and behaviors. The broader aim is to be able to reallocate employees in response to changing demands. Under team based work, temporary teams are formed for particular projects or jobs. Thus there is a continuous shifting of employees that helps the firm maintain its flexibility, and manage costs. In essence these HR practices generate switching options. Accordingly we propose that.

Proposition 4: Firms that have greater uncertainties of combination should create greater number of switching options through job rotation and team based work.

Note that these practices incur significant costs. Job rotation requires a significantly greater number of employees engaging in a significantly greater amount of time in learning new jobs. In addition, the costs of cross training among team members are significant. However, both costs are incurred, as a premium, to manage the uncertainty of combination. As in real options, switching options do not expire till the asset is disinvested. In other words, once the capability for reallocating employees is developed it is easier to maintain it unless there is turnover or changes in employment conditions.

Managing Uncertainties of Cost. Uncertainties related to human capital cost exist when there are high fluctuations in firm performance but the expenses associated with employees are relatively fixed. In such cases these firms should create options to manage 
employee costs through variable compensation plans. Gerhart and Milkovich (1990) noted that organizational and unit level incentive plans render labor costs to be more variable than fixed. Wide use of highly variable compensation plans is found in the sales profession, where under high uncertainty of performance, sales agents are paid on full commission basis (e.g. jewelry sales), while under less uncertain conditions, commission is added to base pay (e.g. financial services sales).

Apart from the extent of variable pay in the total compensation package, variable compensation plans also entail decisions regarding the choice of parameters for measurement of performance, extent of variability of these parameters, and the level of measurement of these parameters. Variable compensation plans that are based on performance can range from individual bonus plans and individual merit pay plans to those based on group/unit/firm performance targets e.g. profit sharing and gain sharing plans. Studies of the performance impact of individual level plans have shown mixed results (Gerhart and Milkovich, 1992). Studies on firm level profit sharing and gain sharing plans, however, have generally shown positive impacts on performance (Gerhart and Milkovich, 1990; Schuster, 1986). We argue that performance based variable plans that are designed at the firm or unit levels generate options to alter costs. Firm or unit level variable compensation plans better align employees' interest with that of the firm, leading to greater transparency, commitment and adaptability on the part of the employees. This creates the opportunity that employees would accept variations in their pay according to variations in firm performance.

In addition, returning to the tremendous costs associated with legacy workforces within mature firms, increasingly firms are engaging in options to reduce this liability. Firms such as IBM have moved their previous "defined benefit" (where the firm promises a set amount of benefits, and must bear the risk for funding the obligation) to "defined contribution" (where the firm contributes to an employee's retirement, but the employee bears all the risk of the investments). The use of the "cash-balance" plans as a means of converting the old system to 
the new system has resulted in considerable cost and conflict, but has been implemented as a means of managing the large fixed cost obligations associated with future retirees.

Thus we propose that,

Proposition 5: Firms that have greater uncertainties of cost should create HR options to alter costs through variable pay and performance based incentive plans at the firm or unit level and defined contribution pension plans.

Note that firms may incur upfront costs in introducing and maintaining these plans, which are the premiums for the options. However, over the long run, the benefits derived from flexibility of costs should offset the premium. Also, once set up, these options do not expire unless there are shifts that change the cost structure.

\section{Discussion}

The field of Strategic HRM has long struggled with determining the ways in which HR practices can create value for firms. While the recent focus on high performance HR practices has yielded promising empirical data to support a relationship between these practices and firm performance (Becker and Huselid, 1998), little is still known about the specific ways in which this value is created (Becker and Gerhart, 1996; Delery, 1998; Wright and Sherman, 1999) and which practices the firm should adopt. Even the hypothesized mechanisms of lower operating costs and creation of inimitable human assets (Becker and Huselid, 1998; Wright, McMahan, and McWilliams, 1994) are based in rather static and cross sectional assumptions about the competitive environment. In addition, the focus on high performance employment practices only narrowly addresses all of the levers that HR can use to manage a firm's workforce.

A real options approach to strategic HRM addresses these issues and provides alternative rationale for value creation through $\mathrm{HR}$ practices. It is complementary to the resource-based view explanation and recommends capability development in stages, through sequential path-dependent investments based on evaluation of uncertainty, as well as through pursuit of opportunities with significant upside potential (McGrath, Ferrier, and Mendelow, 
2004). Therefore this view provides a heuristic guidance on how to create valuable, rare, inimitable and non-substitutable human assets, as prescribed by the resource-based view. In this sense it adds a dynamic component to HR decision making by viewing HR investments as potentially changing in value over time due to uncertainties of human assets. In absence of an explicit analysis of uncertainties of human assets and their management, the resource-based view in strategic HRM provides a partial explanation of the HRM-firm performance relationship.

Additionally, the real options view undertakes a more fine-grained analysis of HR practices to study qualitative variations of the practices that firms use to manage their human assets. For example, we distinguish between selectivity in recruitment for broad-based skills vis-à-vis specialized skills, which allow us to associate it with management of uncertainty of returns of human capital (note: this distinction is different from the human capital theory discussion on 'general' and 'firm-specific' skills because broad-based skills may be firm-specific or applicable in general). Similarly, for training, we highlight training for new skills and learning capabilities as distinct from other forms of training, for generating growth and learning capabilities. These distinctions help answer the question "which HR practices are more relevant for my firm." Therefore the real options framework provides a valuable contribution to understanding the issues inherent in and the role that HRM plays in creating value through human capital for firms in dynamic environments.

\subsection{Limitations}

In extending the real options framework to the field of Strategic HRM, specifically focusing on the management of human capital, some caveats are in order. First, extending real options thinking to human capital relies on the assumption that human capital has value, and that the value changes over time. Currently, the valuation of human capital is at best problematic, and at worst, impossible. However, as noted previously, the valuation of real options is less important than for financial options. More important is the underlying logic for strategic decision-making. Thus, while an ability to place an exact value on all forms of human capital would be quite useful in the application of real options thinking to strategic HRM, it is by 
no means necessary. Rather, the underlying logic of real options provides an extension of how researchers and practitioners can approach the management of uncertainty of human assets and provide an alternative view of value creation.

Second, a criticism against the application of real options theory to strategic HRM may be that at least a part of this framework suggests less commitment towards employees through contingent employees, reallocation of employees, variable pay etc. We disagree because creation of options does not entail reduced commitment towards employees; rather, it calls for stabilizing the employment relationships across a variety of strategic and economic scenarios. Risk in returns for investments in human capital cannot be ignored, and to do so would result in greater, rather than less variability in relationships with employees over time. HR options generate the capability for managing changes incrementally, rather than drastically through layoffs etc., by incorporating different choices in the HRM process. These options specifically act towards not getting into a situation when a firm is forced to separate employees that are no longer required. It may be contended that HR options actually increase a firm's commitment towards its existing employees because the firm is generating alternative choices for managing their employees. In other words organizations using such HR options enhance employeeorganization fit rather than employee-job fit so that when the job changes, the employee still remains valuable to the firm (Tsui et al., 1995).

Third, by no means do we imply that investments in HR options is suitable for all organizations. The extent of use of HR options and their usefulness will depend upon the extent of risks associated with the human capital of the firm. Firms facing greater risks may invest more in options. For example in a high velocity industry, like the IT industry, these HR practices are being used extensively, while they may not be so common in relatively stable industries where HR risks are low. Again, different types of HR options may be used in different industries according to the type of risk present. For example, the risk of volume fluctuations may be more in the trucking industry, while risk of skill fluctuations may be low. A related issue that merits discussion is that of the premium for creating these HR options. Many of these practices involve 
additional investments on human capital. For example selectivity in recruitment for broad-based skills may require highly competitive pay, attractive benefits involve higher costs, higher hourly wages may have to be paid for contingent workers. For this purpose the firm needs to do a judicious cost-benefit analysis in terms of the magnitude of risks and benefits accrued before implementing such practices. There may also be synergistic effects among these HR options that override the costs.

Finally, one could argue that the basic linkages we propose between HR practices and environmental conditions or performance outcomes are certainly not new to the strategic HRM literature. Firms have implemented a variety of the practices we note for arguably, if at least implicitly, the goals of managing risk. However, past explications of these relationships have usually focused purely on cost or revenue considerations as we note previously. An increasingly dynamic environment results in corresponding increases in risk for any investment in human capital. While decision makers may have implemented practices as piecemeal responses to experienced risks, this has been done without an overall framework for thinking about all of the potential types of risk facing the firm's human capital assets. For the field of HRM to ignore an overall evaluation of risks would result in far less than optimal strategic decision-making, especially in view of the contention that many of these options may interact and may have multiplicative effects when implemented together. For example the synergistic effect of selectivity of recruitment for broad-based skills, training for broad-based skills, and skill based pay taken together may be more effective in reducing uncertainty of return, rather than each of them individually. Thus, while these propositions may seem neither new nor unique, they illustrate the usefulness of a coherent framework for examining uncertainties associated with human capital, and the role of HR practices in managing these uncertainties. As McGrath, Ferrier, and Mendelow point out:

"What scholars intrigued by real options reasoning are after is not a displacement of behavioral theories of organizational learning and development, such as slack search......What has been missing in such theories and what real options reasoning 
offers, is insight into the economic logic for how path-dependent processes can be managed intelligently" (2004:98, emphasis added).

\subsection{Future Directions}

We believe that the emphasis on uncertainties in human capital management raises a number of issues that need further investigation. First, this theoretical framework sets the stage for empirically investigating the relationship between different types of risks associated with human capital management, and presence of HR options. Second, as we claim that HR options would have synergistic effects when they act in 'bundles' of multiple interacting options, the need to identify these different 'bundles' exists. For example one way of bundling may be based on the purpose they serve, while another way may be the cross-effects that are generated. Third, individual HR options may manage more than one type of risks. For example variable pay may manage uncertainty of costs and may create learning options. Further research could examine the ways in which individual HR options impact the various forms of risk that we have identified. Also, the list of uncertainties and HR options that we have presented may not be exhaustive. Clearly, uncertainties and options may be different in as we consider different countries of the world, and as we analyze HRM decisions in the international arena. For example the effect of greater influence of unions in countries like Germany and France, may give rise to a separate set on uncertainties, which presents a new avenue of research on uncertainties in human assets.

In conclusion, we use the real options framework to analyze the different types of uncertainties associated with human assets, and the HR practices that may create options to minimize these risks. In doing so we provide a new direction for research in strategic human resource management that acknowledges that investments in human capital are similar to investments in other types of real assets, and thus carry uncertainties. Our purpose is to provide a framework for analyzing these uncertainties and the role of different HR practices that may mitigate the risks to create value for the firm. 


\section{References}

Amram, M., and Kulatilaka, N. (1999) Real Options: Managing Strategic Investment in an Uncertain World. Boston, Massachusetts: Harvard Business School Press.

Arthur, J. B. (1994) Affects of human resource systems on manufacturing performance. Academy of Management Journal, 37(3): 670-687.

Becker, B. and Gerhart, B. (1996) The impact of human resource management on organizational performance: Progress and prospects. Academy of Management Journal, 39: $779-801$.

Becker, B., and Huselid, M. (1998) High performance work systems and firm performance: A synthesis of research and managerial implications. In G. Ferris (Ed) Research in Personnel and Human Resource Management: Vol. 16.

Bowman, E.H., and Hurry, D. (1993) Strategy through the options lens: An integrated view of resource investments and the incremental-choice process. Academy of Management Review, 18(4): 760-782.

Cascio, W. F. (2002) Strategies for responsible restructuring Academy of Management Executive, 16(3): 80.

Colquitt, J.A., LePine, J.A., and Noe, Ra.A. (2000) Toward an integrative theory of training motivation: A meta-analytic path analysis of 20 years of research. Journal of Applied Psychology, 85(5): 678-707.

Delery, J.E. (1998) Issues of fit in strategic human resource management: Implications for research. Human Resource Management Review. 8(3): 289-309.

Delery, J.E., and Doty, D. Harold. (1996) Modes of Theorizing in Strategic Human Resource Management: Tests of Universalistic, Contingency, and Configurational Performance Predictions. Academy of Management Journal, 39(4): 802-835.

Dixit, A. and Pindyck, R. (1994) Investment Under Uncertainty. Princeton, NJ: Princeton University Press.

Foote, D. A., and Folta, T. B. (2002) Temporary workers as real options. Human Resource Management Review, 12:579.

Gale, Jr., H.F., Wojan, T.R., and Olmsted, J.C. (2002) Skills, Flexible Manufacturing Technology, and Work Organization. Industrial Relations, 41(1):48-79.

Gerhart, B., and Milkovich, G.T. (1990) Organizational Differences in Managerial Compensation and Financial Performance. Academy of Management Journal. 33: 663-691.

Gerhart, B., and Milkovich, G.T. (1992) Employee compensation: Research and Practice. In M.D. Dunnette and L.M. Hough (eds.) Handbook of Industrial and Organizational Psychology (2 ${ }^{\text {nd }}$ ed.), 3: 481-569. Palo Alto, CA: Consulting Psychologists Press.

Griffeth, R.W., and Hom, P.W. (1995) The employee turnover process. In G.R. Ferris (Ed.) Research in Personnel and Human Resources Management, 13: 245-293. Greenwich, CT: Jai Press. 
Hamel, G., and Prahalad, C.K. (1994) Competing for the Future. Boston, MA: Harvard Business School Press.

Huselid, M. A. (1995) The impact of human resource management practices on turnover, productivity, and corporate financial performance. Academy of Management Journal, 38(3): 635-672.

Kogut, B., and Kulatilaka, N. (2001) Capabilities as real options. Organization Science, 12: 744758.

Lawler, E.E., III, and Ledford, G.E., Jr. (1985) Skill-based pay - A concept that's catching on. Personnel. 62: 30-37.

Leiblen, M. J. (2003) The choice of organizational governance form and performance: Predictions from transactions cost, resource-based, and real options theories. Journal of Management, 29:903.

Lepak, D.P., and Snell, S.A. (1999) The human resource architecture: Toward a theory of human capital allocation and development. Academy of Management Review, 24(1): 3148.

Matusik, S.F., and Hill, C.W. (1998) The utilization of contingent work, knowledge creation, and competitive advantage. Academy of Management Review, 23(4): 680-697.

McElroy, J.C., Morrow, P.C.and Rude, S.N. (2001) Turnover and organizational performance: A comparative analysis of the effects of voluntary, involuntary, and reduction-in-force turnover. Journal of Applied Psychology, 86:1294.

McGrath, R. G., Ferrier, W. J., and Mendelow, A. L. (2004) Real options as engines of choice and heterogeneity. Academy of Management Review, 29:86-101.

Murray, B. and Gerhart, B. (1998) An empirical analysis of a skill-based pay program and plant performance outcomes. Academy of management Journal, 41(1): 68-78.

Peterson, R.B., and Tracy, L. (1992) Assessing effectiveness of joint committees in a labormanagement cooperation program. Human Relations, 45(5): 467-488.

Purcell, J. (1998) High commitment management and link with contingent workers: Implications for strategic human resource management. In Research in Personnel and Human Resource Management, supplement 4: 239-257. Greenwich, CT: jai Press.

Schuster, M. (1986) Gainsharing: The state of the art. Compensation and Benefits Management. 2: 285-290

Shaw, J.D., Delery, J.E., and Gupta, N. (1998) An organization-level analysis of voluntary and involuntary turnover. Academy of Management Journal, 41(5): 511-525.

Snell, S.A., and Dean, J. W., Jr. (1994) Strategic Compensation for Integrated Manufacturing: The Moderating Effects of Jobs and Organizational Inertia. Academy of Management Journal, 37: 1109-1140. 
Snell, S.A., Youndt, M. and Wright, P. (1996) Establishing a Framework for Research in strategic human resource management: Merging resource theory and organizational learning. In G. Ferris (Ed.), Research in Personnel and Human Resource Management, 14: $61-90$.

Trigeorgis, L. (1996) Real Options: Managerial Flexibility and Strategy in Resource_Allocation. Cambridge, MA: MIT Press.

Tsui, A. S., Pearce, J.L., Porter, L.W. and Hite, J. (1995) Choice of employee-organization relationship: Influence of external and internal organizational factors." In Ferris, J. (Ed.), Research in Personnel and Human Resource Management, 13: 117-151.

Ulrich, D. and Lake, D. (1990) Organizational capability: Competing from the inside/out. New York: Wiley.

Wager, T.H. (1997) Is labor-management climate important? Some Canadian evidence. Journal of Labor Research, 17(1): 163-174.

Wright, P. M., Dunford, B.B., and Snell, S. A. (2001) Human resources and the resource-based view of the firm. Journal of Management, 27: 701-721.

Wright, P.M., McMahan, G., and McWilliams, A. (1994) Human resources and sustained competitive advantage: A resource-based perspective. International Journal of Human Resource Management, 5: 301-326.

Wright, P.M. and Sherman, S. (1999) The failure to find fit in strategic human resource management: Theoretical and empirical considerations. In P. Wright, L. Dyer, J. Boudreau, and G. Milkovich (Eds.) Research in Personnel and Human Resource Management, Supplement 4, 53-74.

Wright, P. M., and Snell, S. A. (1998) Toward a unifying framework for exploring fit and flexibility in strategic human resource management. Academy of Management Review, 23: $756-772$. 